Cambridge University Press

0521837588 - Women and Religious Writing in Early Modern England

Erica Longfellow

Frontmatter

More information

\title{
WOMEN AND RELIGIOUS WRITING IN EARLY MODERN ENGLAND
}

This study challenges critical assumptions about the role of religion in shaping women's experiences of authorship. Feminist critics have frequently been uncomfortable with the fact that conservative religious and political beliefs created opportunities for women to write with independent agency. The seventeenth-century Protestant women discussed in this book range across the religio-political and social spectrums and yet all display an affinity with modern feminist theologians. Rather than being victims of a patriarchal gender ideology, Lady Anne Southwell, Anna Trapnel and Lucy Hutchinson, among others, were both active negotiators of gender and active participants in wider theological debates. By placing women's religious writing in a broad theological and socio-political context, Erica Longfellow challenges traditional critical assumptions about the role of gender in shaping religion and politics, and the role of women in defining gender and thus influencing religion and politics.

ERICA LONGFELlow is Senior Lecturer in English Literature at Kingston University. She is co-coordinator of the Performing History project in association with Hampton Court Royal Palace, which aims to reproduce early modern dramatic performances in historical settings. 


\section{WOMEN AND RELIGIOUS WRITING IN EARLY MODERN ENGLAND}

BY

ERICA LONGFELLOW 


\section{Cambridge University Press}

0521837588 - Women and Religious Writing in Early Modern England

Erica Longfellow

Frontmatter

More information

PUBLISHED BY THE PRESS SYNDICATE OF THE UNIVERSITY OF CAMBRIDGE

The Pitt Building, Trumpington Street, Cambridge, United Kingdom

CAMBRIDGE UNIVERSITY PRESS

The Edinburgh Building, Cambridge, СB2 2RU, UK

40 West 2oth Street, New York, NY IOOII-42II, USA

477 Williamstown Road, Port Melbourne, vic 3207, Australia

Ruiz de Alarcón I3, 280I4 Madrid, Spain

Dock House, The Waterfront, Cape Town 8oor, South Africa

http://www.cambridge.org

(C) Erica Longfellow 2004

This book is in copyright. Subject to statutory exception and to the provisions of relevant collective licensing agreements,

no reproduction of any part may take place without

the written permission of Cambridge University Press.

First published 2004

Printed in the United Kingdom at the University Press, Cambridge

Typeface Adobe Garamond II/I2.5 pt. System $\mathrm{HT}_{\mathrm{E}}{ }_{2 \varepsilon} \quad$ [тв]

A catalogue record for this book is available from the British Library

ISBN O 52I 837588 hardback 


\section{Contents}

Acknowledgements

Abbreviations

page vi

Note on transcription and citation

Introduction

I 'Blockish Adams' on mystical marriage

2 Ecce homo: the spectacle of Christ's passion in Salve deus rex judaorum

3 Serpents and doves: Lady Anne Southwell and the new Adam 92

4 Public worship and private thanks in Eliza's babes

5 Anna Trapnel 'sings of her Lover'

6 The transfiguration of Colonel Hutchinson in Lucy

Hutchinson's elegies

Conclusion

Bibliography

Index

236

Index to scripture passages 


\section{Acknowledgements}

Thanks are due to Malcolm Parkes, Sylvia Brown and Nigel Smith for early advice and encouragement. Elizabeth Clarke has been a continual influence, offering her advice and the resources of the Perdita Project, and being the first to introduce me to several of the writers discussed here.

I have also been encouraged by a genuinely supportive and stimulating community of scholars of early modern women, particularly the participants in the Oxford University 'Women, Text \& History' seminar and the Early Modern Women's Manuscript conferences affiliated with the Perdita Project. Of these, Sarah Ross, Victoria Burke, Sister Jean Klene, Alexandra Shepard and Liam Semler sent me volumes of work-in-progress and research notes without which this study could not have been written. Along with so many scholars of my generation, I benefited from the generous advice and prodigious scholarly resources of the late Jeremy Maule. Conversations with Jane Shaw, Emma Jay, Natasha Distiller and Jonathan Gibson urged me to think further. John Carey, Peter Davidson and David Norbrook were forthcoming with advice, critique and sources. Alison Shell, Jessica Martin and Hero Chalmers all shared insightful responses to my writing samples. Andrew Gregory, Alan Le Grys and Jeremy Worthen were forthcoming with excellent theological advice. Elisabeth Dutton brought me up to speed on medieval devotional literature.

I owe a debt of gratitude to my research supervisor, Peter McCullough, for his continual enthusiasm for the project and ongoing friendship. Likewise, Tom Betteridge and Norma Clarke provided encouragement and critique at crucial moments. Emma Jay, Erica Wooff, Suzanna Fitzpatrick and Andrew Van der Vlies found the errors I could no longer see.

For graciously allowing me access to sources under unusual circumstances, I am grateful to the conservation department of the Bodleian Library, the rare books and manuscripts librarians of the Huntington Library and the Codrington Library of All Souls' College, Oxford. I also received valuable advice and assistance from the staff of the Beinecke Rare 
Cambridge University Press

o521837588 - Women and Religious Writing in Early Modern England

Erica Longfellow

Frontmatter

More information

Acknowledgements

vii

Book and Manuscript Library, the British Library, the Greater London Record Office, the Public Record Office (now the National Archives) and the William Andrews Clark Memorial Library.

My thanks are also due to the Oxford University Graduate Studies Board and the Rector and Fellows of Lincoln College for providing me with vital financial support for research abroad, and to the Kingston University School of Humanities, particularly David Rogers and Avril Horner, for supporting this project throughout with research leave, grants and timely advice.

This book is dedicated to my parents, for always believing that I could do whatever I put my mind to.

Earlier versions of chapters 3 and 4 have previously appeared in print as: 'Eliza's Babes: Poetry "Proceeding from Divinity" in Seventeenth-Century England'. Gender and History I4.2 (2002): 242-65. 'Lady Anne Southwell's Indictment of Adam'. In Early Modern Women's Manuscript Writing: Selected Papers from the Trinity/Trent Colloquium. Edited by Victoria Burke and Jonathan Gibson. Aldershot: Ashgate; 2004, III-33. They are reproduced here with permission. 
Cambridge University Press

0521837588 - Women and Religious Writing in Early Modern England

Erica Longfellow

Frontmatter

More information

\section{Abbreviations}

CSPD Calendar of State Papers, Domestic

CSPI Calendar of State Papers, Ireland

DNB Dictionary of National Bibliography on CD-ROM (Oxford: Oxford University Press, 1995)

ELH English Literary History

ELR English Literary Renaissance

HMC Historical Manuscripts Commission Reports

LIT LIT: Literature, Interpretation, Theory

MLQ Modern Language Quarterly

OED Oxford English Dictionary Online (Oxford: Oxford University Press, 2000)

PRO Public Record Office (now the National Archives)

STC A. W. Pollard et al., eds., A short-title catalogue of books printed in England, Scotland \& Ireland and of English books printed abroad, I475-I640, 2nd edn (London: Bibliographical Society, 199I)

Wing Donald Wing, ed., Short-title catalogue of books printed in England, Scotland, Ireland, Wales, and British America and of English books printed in other countries, I64I-I700, 2nd edn, New York: Modern Language Association, 1994 


\section{Note on transcription and citation}

Quotations from early modern texts retain the original spelling and punctuation; only the long ' $s$ ' has been regularised. In transcriptions from manuscript, brackets pointing inward $><$ indicate insertions above the line of text, while brackets pointing outward $<>$ signify deletions. Square brackets [] indicate the expansion of an abbreviation or editorial interpolations. The footnotes indicate where manuscript corrections have been silently omitted or incorporated. In transcriptions from early printed books, italicisation, underlining and in some cases capitalisation have been ignored where these are used to distinguish a line or block of text (such as on title pages), but retained where they indicate emphasis.

For the ease of anyone wishing to locate a particular edition, I have included STC and Wing numbers and the names of printers, publishers and booksellers in references to all early modern books. I have followed STC convention in using short titles and capitalising only the first letter of a title.

All quotations from scripture are from the Authorised Version of the Bible. 